INFORMAATIOTUTKIMUKSEN PÄIVÄT 2020

\title{
Yrittäjyyden representaatiot kotimaisissa sanomalehdissä
}

Max Peltonen

Oulun yliopisto

max.peltonen@student.oulu.fi

Markus Rytinki

Heidi Enwald

Anna-Mari Simunaniemi

Leena Eskola

Asiasanat: diskurssi, diskurssianalyysi, informaatiotutkimus, representaatio, sanomalehdet, yritykset, yrittäjät, yrittäjyys

Tutkimuksessa lähdettiin selvittämään yrittäjyyden näkyvyyttä kotimaisissa sanomalehdissä seuraavan kahden tutkimuskysymyksen kautta:

1. Ketkä toimijat/toimijaryhmät osallistuvat sanomalehdissä käytäviin yrittäjyyttä koskeviin diskursseihin?

2. Minkälaisia diskursseja yrittäjyydestä ja yrityksistä teksteissä on havaittavissa? Kuinka eri toimijaryhmät osallistuvat diskursseihin?

Artikkeli on lisensoitu Creative Commons Nimeä-EiKaupallinen-JaaSamoin 4.o Kansainvälinen -lisenssillä

Pysyvä osoite: https://doi.org/10.23978/inf.99124 


\section{Tausta}

Median tarjoama tieto, ja sen tapa käsitellä erilaisia asioita, vaikuttaa siihen, millainen kuva meillä maailmasta ja sen tapahtumista on. Sanomalehtien erilaisissa sisällöissä on suuri määrä potentiaalisia puhujia vaihtelevine yhteiskunnallisine asemineen aina toimittajista ja päättäjistä tavallisiin kansalaisiin unohtamatta itse yrittäjiä. Tämän vuoksi on hyödyllistä tehdä tutkimusta siitä, kuka yrittäjyydestä on kertomassa.

Representaatiolla eli edustamisella voidaan tarkoittaa taiteellisen tai kielellisen kuvaamisen sekä poliittisen edustamisen kaltaisia asioita. Tieteissä representaatioilla voidaan tarkoittaa erilaisia teoreettisia rakennelmia ja merkkijärjestelmiä. Moderni maailma on täynnä tilanteita, joissa jokin asia edustaa jotakin toista. (Knuuttila \& Lehtinen 2010, 7, 10.) Paitsi että representaatiot välittävät ja heijastelevat todellisuutta, voivat ne myös poiketa kohteestaan tai olla aktiivisesti vaikuttamassa reaalimaailmaan. Kenelle kuuluu valta puhua ja kenen puolesta?

Diskursseilla tarkoitetaan erilaisia keskustelukokonaisuuksia ja -konteksteja. Se, millä tavalla kukin osapuoli pääsee osallistumaan keskusteluun tai jää sen ulkopuolelle perustuu monesti olemassa oleviin konventioihin (Paso 2007, 36). Diskurssianalyysi on konkreettisen yksittäisen metodin sijaan pikemminkin tutkimuksellinen lähestymistapa; monia teorioita ja metodeja yhdistävä viitekehys tieteen tekemiselle (Jokinen, Juhila, \& Suoninen 2017, 21). Diskurssianalyysin tekemisessä yhdistetään kieli- ja yhteiskuntatieteellisiä näkemyksiä toisiaan tukevaksi vuorovaikutukseksi, jolloin sidotaan tekstin muodostamaa todellisuutta ja yhteiskunnallista keskustelua tieteellisesti käsiteltävissä oleviksi rakenteiksi. Mahdollinen tapa soveltaa diskurssianalyysiä on tarkastella tekstissä esiintyviä toiminnan ja osallistujien tyyppejä ja joukkoja, sekä sitä minkälaisia ilmauksia näistä tahoista käytetään. (Paso 2007, 29-31.)

Yrittäjyydessä on keskiössä yksilö, joka on omavarainen ja itsenäinen toimija. Yrittäjyyteen liittyvän ihmiskuvan keskiössä on Frederick Douglasin ja Benjamin Franklinin self-made man, joka tekee kovasti töitä tiukalla moraalilla. Yrittäjä voidaan nähdä määrätietoisena, luovana ja uskaliaana toimijana, joka kehittää uusia teknologioita eikä ole sitoudu perinteisiin ja tutunnaisiin toimintamalleihin. (Kantola \& Kuusela 2019, 131.) Onko niin, että mediat ja yrittäjät puhuvat yrittäjyydestä samalla tavalla? Vai poikkeavatko representaatiot toisistaan, ja jos, niin miten ja miksi? 


\section{Tutkimus}

Tutkimuksen aineistoksi otettiin paperipainoisia julkaisuja seuraavilta neljältä kotimaiselta sanomalehdeltä: Helsingin Sanomat, Iltalehti, Kaleva ja Kauppalehti. Rajauksen tavoitteena oli saavuttaa mahdollisimman monipuolinen ja valtakunnallisesti merkittävä kuva suomalaisen printtimedian välittämästä yrittäjyyskuvasta. Helmikuilta 2019 ja 2020 poimittujen lehtien joukosta etsittiin artikkeleita, joissa yrityksiä ja yrittäjiä oli tavalla tai toisella mainittu tai käsitelty. Aineiston lopullinen saanti oli 295 artikkelia 16 sanomalehtinumerosta.

Analyysin ensimmäinen osa toteutettiin määrällisenä tutkimuksena. Ensin tarkasteltiin sanomalehtijutuissa esiintyneitä henkilöitä, jotka järjestettiin toimijajoukoiksi kuten yrittäjät, toimittajat, muut asiantuntijat sekä viranomaiset. Tämän jälkeen kyseisten ryhmien osuutta eli esiintyvyyttä ja yleisyyttä tarkasteltiin ja arvioitiin. Tuloksena saatiin selville, kuinka usein lehdistö hakee yrityksen itsensä edustajia aiheeseen liittyvissä teksteissä ja täten missä määrin yrityksillä ja yrittäjillä on mahdollisuus vaikuttaa näkyvyyteensä mediassa. Myös ryhmien koostumuksesta oli muodostettavissa kiinnostavia huomiota: esimerkiksi millaisia yritysten ja lehdistön ulkopuolisia toimijoita oli haettu esiintymään asiantuntijan roolissa.

Analyysin toisessa vaiheessa tutkittiin aineiston lehtiartikkeleissa esiintyneitä yrityksiin ja yrittäjyyteen liittyviä diskursseja. Diskursseja tunnistettiin yhteensä kuusi kappaletta, joista jokainen tarjosi mielenkiintoisen näkökulman tällä hetkellä sanomalehdistössä vallitseviin yrityksiin ja yrittäjyyteen liittyviin keskustelukokonaisuuksiin ja -konteksteihin.

\section{Lähteet}

Jokinen, A., Juhila, K., \& Suoninen, E. (2017). Diskurssianalyysi: Teoriat, peruskäsitteetja käyttö. Tampere: Vastapaino.

Kantola, A., \& Kuusela, H. (2019). Huipputuloiset. Suomen rikkain promille. Tampere: Vastapaino.

Knuutila, T., \& Lehtinen, A. (2010). Johdanto: Representaatio - tiedon kivijalasta tieteiden työkaluksi. Teoksessa: T. Knuutila \& A. Lehtinen (toim.), Representaatio: Tiedon kivijalasta tieteiden työkaluksi (s. 7-31). Helsinki: Gaudeamus Helsinki University Press.

Paso, E. (2007). Työkyky merkitsee: työkyvyn merkityksen ja maailman rakentuminen lehtiteksteissä. Väitöskirja. Oulu: Oulun yliopisto. 